\title{
Development of Computer Literacy Courseware for Rural Children Using Sarawak Borneo Local Dialects
}

\author{
S.H. Subri \\ Department of Computing and Software Engineering \\ Universiti Malaysia Sarawak \\ 94300 Kota Samarahan, Sarawak, Malaysia \\ syanis88@gmail.com
}

\begin{abstract}
In the last decade, computers have become important equipment especially for classroom teaching and help students to learn better. This paper reports the design and development of a courseware to introduce computer literacy for Sarawak rural children. We believe this is the first attempt to create a comprehensive courseware totally in Sarawak Malay dialect and Iban Language. The application is designed in Borneo's Sarawak Malay dialect and Bahasa Iban. The courseware contains eight learning modules with focus on the topics about basic computer knowledge. In the evaluation stage, we involved students and asked their comments about the courseware. The testing results revealed that using our courseware, the rural children are excited and satisfied to learn basic computer literacy.
\end{abstract}

Keywords-computer literacy, rural informatics, localization.

\section{REFERENCES}

[1] M. Saçkes, K. C. Trundle, and R. L. Bell, "Young children's computer skills development from kindergarten to third grade,' Computers \& Education, vol. 57, no. 2, pp. 1698-1704, Sep. 2011.

[2] Ö. Yurt and N. Cevher-Kalburan, "Early childhood teachers' thoughts and practices about the use of computers in early childhood education," Procedia Computer Science, vol. 3, pp. 1562-1570, Jan. 2011.

[3] N. Tosun and M. F. Baris, "The Place and Importance of Computer and Internet's In Secondary School Students' Life," Procedia Social and Behavioral Sciences, vol. 28, pp. 530-535, Jan. 2011.

[4] Y. Zhou, N. Singh, and P. D. Kaushik, "The digital divide in rural South Asia: Survey evidence from Bangladesh, Nepal and Sri

\author{
S.N. Junaini \\ Department of Computing and Software Engineering \\ Universiti Malaysia Sarawak \\ 94300 Kota Samarahan, Sarawak, Malaysia \\ syahruln@fit.unimas.my
}

Lanka,” IIMB Management Review, vol. 23, no. 1, pp. 15-29, Mar. 2011.

[5] N. F. M. Nora, N. A. Razaka, M. Y. Abdullaha, J. A. Maleka, and A. Salmana, "Empowering marginalized community with an innovative technology," Procedia - Social and Behavioral Sciences, vol. 15, pp. 3374-3378, Jan. 2011

[6] K. Gyabak and H. Godina, "Digital storytelling in Bhutan: A qualitative examination of new media tools used to bridge the digital divide in a rural community school," Computers \& Education, vol. 57, no. 4, pp. 2236-2243, Dec. 2011.

[7] M. B. Yilmaz, "Opinions of Primary School Teachers on Their Students'ICT Skills and Information Technologies Course," Procedia - Social and Behavioral Sciences, vol. 28, pp. 503-509, Jan. 2011.

[8] H. Fatemeh, K. Ahmad, and D. M. Mohammad, "ICMAP: An interactive tool for concept map generation to facilitate learning process," Procedia Computer Science, vol. 3, pp. 524-529, Jan. 2011

[9] R. Mohamad and T. S. Chong, "An adaptive multimedia courseware for the students' different cognitive styles: a pilot study for history subject," Procedia Computer Science, vol. 3, pp. 301-306, Jan. 2011

[10] Y.-T. Sung, K.-E. Chang, and W.-C. Yu, "Evaluating the reliability and impact of a quality assurance system for E-learning courseware," Computers \& Education, vol. 57, no. 2, pp. 1615 1627, Sep. 2011

[11] Y. K. Türel, "An interactive whiteboard student survey: Development, validity and reliability," Computers \& Education, vol. 57, no. 4, pp. 2441-2450, Dec. 2011.

[12] C.-M. Chen, "Intelligent web-based learning system with personalized learning path guidance," Computers \& Education, vol. 51, no. 2, pp. 787-814, Sep. 2008. 